\title{
Teaching NeuroImages: \\ First-order Horner syndrome due to ipsilateral thalamic hemorrhage
}

Nicholas Alfred Blondin, MD

Joseph Laurence Schindler, MD

Address correspondence and reprint requests to Dr. Nicholas Alfred Blondin, Department of

Neurology, Yale University School of Medicine,

New Haven, CT 06519

nicholas.blondin@yale.edu
A 56-year-old man with no past medical history developed a left facial droop, dysarthria, and left arm weakness. He was found to have an acute right thalamic hemorrhage. On further examination, he was found to have right-sided ptosis and miosis, with anisocoria more marked in the dark than in light (figure, A). He was also found to have right-sided facial anhidrosis.

CT angiogram showed no evidence of carotid dissection. The patient's Horner syndrome was due to a first-order neuron lesion in the posterior nucleus of the right hypothalamus or proximal CNS sympathetic tract (figure, B and C). ${ }^{1,2}$

\section{REFERENCES}

1. Nagy AN, Hayman LA, Diaz-Marchan PJ, Lee AG. Horner's syndrome due to first order neuron lesions of the oculosympathetic pathway. AJR Am J Roentgenol 1997;169:581-584.

2. Reede DL, Garcon E, Smoker WR, Kardon R. Horner's syndrome: clinical and radiographic evaluation. Neuroimaging Clin N Am 2008;18:369-385.
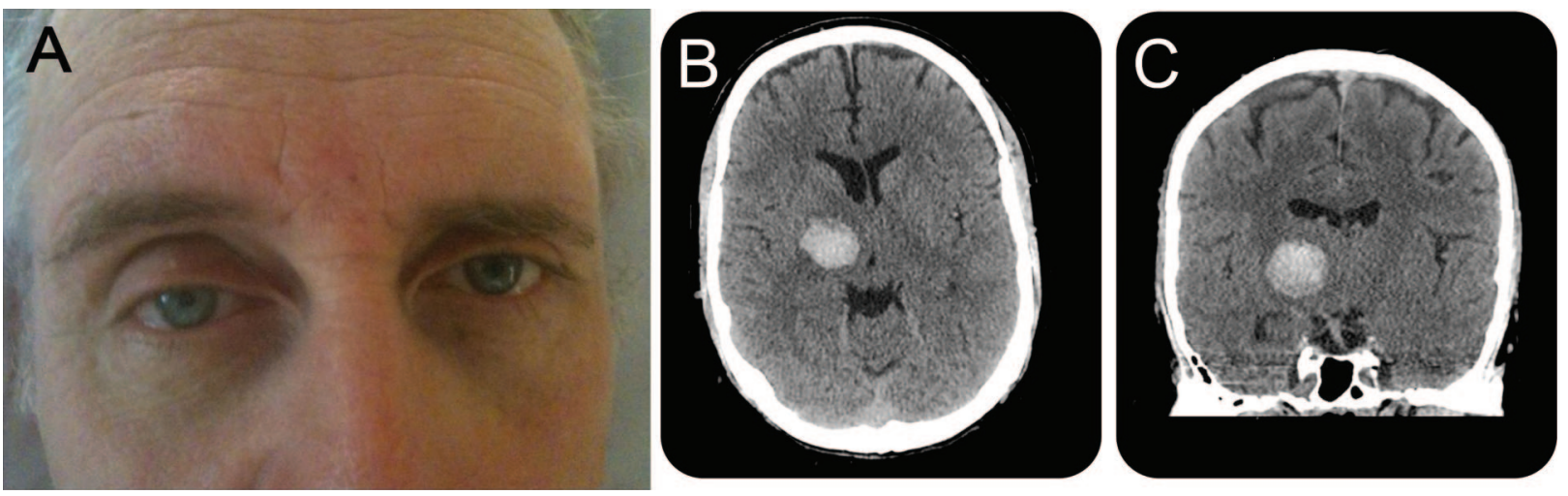

(A) The patient shows right-sided ptosis and miosis. A prominent left lower facial droop was also present. (B) Axial and (C) coronal noncontrast CT scan of the brain show acute right thalamic hemorrhage. 


\section{Neurology}

\section{Teaching NeuroImages: First-order Horner syndrome due to ipsilateral thalamic hemorrhage}

Nicholas Alfred Blondin and Joseph Laurence Schindler

Neurology 2011;76;e14

DOI 10.1212/WNL.0b013e31820882db

\section{This information is current as of January 24, 2011}

\section{Updated Information \&} Services

References

Citations

Subspecialty Collections

Permissions \& Licensing

Reprints including high resolution figures, can be found at: http://n.neurology.org/content/76/4/e14.full

This article cites 2 articles, 0 of which you can access for free at: http://n.neurology.org/content/76/4/e14.full\#ref-list-1

This article has been cited by 1 HighWire-hosted articles: http://n.neurology.org/content/76/4/e14.full\#\#otherarticles

This article, along with others on similar topics, appears in the following collection(s):

\section{All Cerebrovascular disease/Stroke}

http://n.neurology.org/cgi/collection/all_cerebrovascular_disease_strok e

All Education

http://n.neurology.org/cgi/collection/all_education

\section{CT}

http://n.neurology.org/cgi/collection/ct

Intracerebral hemorrhage

http://n.neurology.org/cgi/collection/intracerebral_hemorrhage

Information about reproducing this article in parts (figures,tables) or in its entirety can be found online at:

http://www.neurology.org/about/about_the_journal\#permissions

Information about ordering reprints can be found online:

http://n.neurology.org/subscribers/advertise

Neurology ${ }^{\circledR}$ is the official journal of the American Academy of Neurology. Published continuously since 1951, it is now a weekly with 48 issues per year. Copyright Copyright (? 2011 by AAN Enterprises, Inc.. All rights reserved. Print ISSN: 0028-3878. Online ISSN: 1526-632X.

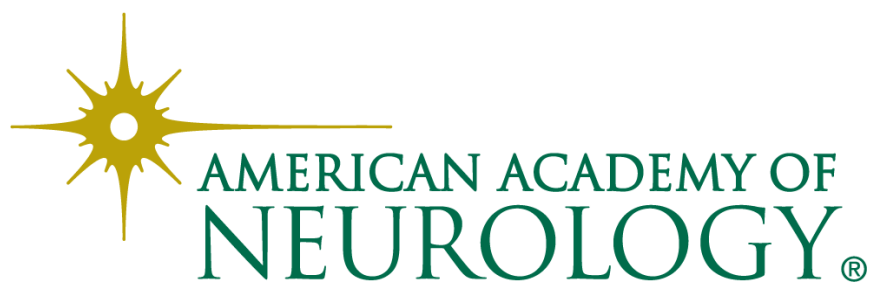

